\title{
Peran Notaris Dalam Menegakkan Good Corporate Governance pada Perbankan Syariah
}

\author{
Ina Faturohmah \\ nftr.1234@gmail.com
}

\begin{abstract}
One form of the implementation of good corporate governance in Islamic Banking is the actualization of sharia compliance. Sharia compliance lies not only on the products but also on the operational aspect of business activities, including contracts. In short, effective GCG means clarity in the contracts. In conducting business activities, contracts become the basis for the realization of business activities, one of which is financing activities. A written agreement on financing made by and before a Notary becomes an authentic deed with perfect proof of evidence. Therefore, a Notary can play a role in supporting the enforcement of GCG in a sharia bank. This study was normative legal research, aimed to provide legal arguments over a legal case and to assess it as well as to answer how it should be according to law. The results showed that in banking business activities, especially financing, a Notary plays a role in enforcing GCG in sharia banks, and that it is a good important role to support the actualization of GCG in banking. However, the role of Notary must be in accordance with Law No. 2 of 2014 on Amendment to Law No. 30 of 2004 on Notary.
\end{abstract}

KeywordS : Good corporate governance; sharia banking; contract; notary

\begin{abstract}
Abstrak
Salah satu wujud dari penerapan good corporate governance (GCG) pada Perbankan Syariah adalah terwujudnya kepatuhan syariah. Kepatuhan Syariah bukan hanya terletak pada hal produk, tetapi juga pada aspek operasional kegiatan usaha, termasuk di dalamnya adalah kontrak. Singkatnya, GCG yang efektif adalah adanya suatu kejelasan dalam kontrak. Dalam melakukakan kegiatan usaha, kontrak adalah dasar terlaksananya realisasi kegiatan usaha,salah satunya adalah kegiatan pembiayaan. Kesepakatan tertulis mengenai pembiayaan yang dibuat oleh dan di hadapan Notaris menjadi akta otentik yang memiliki kekuatan pembuktian sempurna, maka dari itu Notaris dapat berperan dalam mendukung penegakkan GCG di Bank Syariah. Penelitian hukum ini adalah penelitian hukum normatif, dilakukan dengan maksud untuk memberikan argumentasi hukum mengenai suatu peristiwa hukum dan menilainya serta menjawab bagaimana sebaiknya peristiwa itu menurut hukum. Hasil dari penelitian menyimpulkan bahwa, didalam kegiatan usaha bank khususnya pembiayaan, ada peran Notaris dalam menegakkan GCG di Bank Syariah, dan peran tersebut menjadi peran yang baik dan penting dalam mendukung terwujudnya Bank melaksanakan GCG, tetapi peran Notaris yang dilaksanakan tersebut harus sesuai dengan Undang-Undang Nomor 2 Tahun 2014 tentang Perubahan Atas Undang-Undang Nomor 30 Tahun 2004 Tentang Jabatan Notaris.
\end{abstract}

Kata-kata Kunci: Good corporate governance; perbankan syariah; kontrak; notaris 


\section{Pendahuluan}

Bank Indonesia selalu menyampaikan banyaknya indikasi pelanggaran syari'ah yang dilakukan oleh lembaga perbankan syari'ah dalam praktek operasionalnya. Hal senada juga diungkapkan Deputi Gubernur Bank Indonesia Maulana Ibrahim dalam seminar bertajuk "Prospek Perbankan Syariah PascaFatwa MUI", di Jakarta, 10 Pebruari 2004. Maulana mengatakan bahwa, "Dari indikator pengawasan dan pemeriksaan yang dilaporkan Bank Indonesia, masih ditemui berbagai sistem operasional bank syariah yang belum sesuai dengan prinsip kepatuhan pada nilai-nilai syariah. Industri perbankan syari'ah sejatinya dijalankan berdasarkan prinsip dan sistem syari'ah. Karena itu, kesesuaian operasi dan praktek bank syariah dengan syari'ah merupakan piranti mendasar dalam perbankan syari'ah. ${ }^{1}$

Good Corporate Governance perbankan syariah dapat dikatakan bahwa demi terciptanya bisnis ekonomi syariah yang sehat, yang memenuhi prinsip-prinsip Islam dalam transaksi di bank syariah, maka salah satunya adalah hubungan antara nasabah dan bank syariah tersebut haruslah kuat, hubungan yang adil, hubungan yang setara atas kedudukan masing-masing hak dan kewajiban yang digaris bawahi dengan peran suatu akad atau kontrak yang dibuat atau dihadapan Notaris atau PPAT dalam membuat Akta baik itu akta autentik ataupun akta dibawah tangan harus memperhatikan dan menerapkan peraturan-peraturan yang berlaku, nilai-nilai agama, prinsip Islam, norma serta notaris dituntut untuk melaksanakan hal-hal yang mendorong terciptanya good corporate governance di perbankan syariah.

Penerapan GCG di bank syariah harus memenuhi kepatuhan pada prinsip syariah, implementasi GCG di bank syariah tidak bisa dipisahkan dari kewajibannya untuk menjalankan kegiatan usaha yang berdasarkan prinsip syariah. Hal inilah yang membedakannya dengan penerapan GCG di bank konvensional.

\footnotetext{
1 M.Nazori Madjid“ Nuansa Konvensional dalam Perbankan Syariah” dalam http://download.portalgaruda.org/ diakses pada 09 September 2017 Pukul 21.00 WIB
} 
Kewajiban Dewan Syariah masih menekankan pada upaya memastikan kepatuhan syariah dalam hal produk dibandingkan dengan aspek operasional dari bisnis perbankan Islam, fakta ini haruslah dijadikan sebagai pertimbangan, bahwa dalam regulasi yang ada saat ini belum banyak menyertakan aspek operasional sebagai bagian tak terpisahkan bagi kriteria kepatuhan syariah. Panduan yang lebih detail dari kepatuhan syariah dalam tata kelola atau good corporate governance penting untuk segera di tindaklanjuti dengan implementasi yang jelas, karena hal ini bisa memberikan dukungan dalam mewujudkan kepatuhan syariah untuk keseluruhan sistem perbankan Islam. ${ }^{2}$

Kontrak adalah suatu hal yang sangat krusial dalam proses perbankaan syariah, karena itu kontrak merupakan salah satu penentu terlaksananya GCG. Salah satu Pilar dari penerapan corporate governance yang efektif adalah adanya suatu kejelasan dalam kontrak. Operasional perbankan syariah adalah identik dengan penerapan dari kontrak keuangan, kontrak syariah atau akad yang menjadi dasar apakah corporate governance di perbankan syariah tersebut telah terlaksana.

Kontrak secara teknis dapat diartikan sebagai instrumen atau piranti berupa akta perjanjian yang sengaja dibuat tertulis sebagai alat bukti di antara dua orang atau lebih atau badan hukum yang menciptakan hak dan kewajiban untuk melakukan atau tidak melakukan sesuatu hal yang disebutkan di dalamnya.

Kontrak atau perjanjian yang dituang dalam tulisan yang khusus dibuat untuk dijadikan bukti atas suatu hal yang disebut di dalamnya, dalam lalu lintas Perbuatan Hukum yang begitu nyata, Bank sebagai lembaga keuangan hampir sebagian besar atau seluruhnya membutuhkan Notaris, Notaris dalam hal ini membuat kontrak atau akta dalam aktifitas perbankan syariah diperlukan dalam: 1. melakukan berbagai kerjasama; 2. transaksi keuangan; 3. Diperlukan dalam kaitannya dengan nasabah (produk perbankan); dan 4. Pengikatan jaminan.

Notaris adalah penyedia jasa hukum yang bekerja untuk kepentingan klien. Profesi notaris diatur dalam perundang-undangan namun aturan hukum positif tidak sampai menjangkau pada teknis pekerjaan notaris. ${ }^{3}$ Dengan demikian, hubungan hukum antara penghadap dengan notaris bukanlah hubungan 
kontrakual antara satu pihak dengan pihak lainnya. Tidak terdapat perjanjian baik lisan maupun tertulis yang diadakan oleh para pihak dengan notaris. Para pihak datang sendiri kepada notaris untuk membuat akta yang mereka inginkan. ${ }^{4}$

Menurut Undang-Undang Nomor 2 Tahun 2014 tentang Perubahan Atas Undang-Undang Nomor 30 Tahun 2004 tentang Jabaran Notaris atau selanjutnya disebut UUJN-P, Notaris adalah pejabat umum yang berwenang untuk membuat akta autentik dan memiliki kewenangan lainnya sebagimana dimaksud dalam UU ini atau berdasarkan undang-undang lainnya. Kewenangan Notaris yang disebutkan oleh Pasal 15 UUJN-P adalah Notaris Berwenang membuat Akta autentik mengenai semua perbuatan, perjanjian, dan penetapan yang diharuskan oleh peraturan perundang-undangan dan/atau yang dikehendaki oleh yang berkepentingan untuk dinyatakan dalam akta autentik, menjamin kepastian tanggal pembuatan akta, menyimpan akta, memberikan grosse, salinan, dan kutipan akta, semuanya itu sepanjang pembuatan akta itu tidak juga ditugaskan atau dikecualikan kepada pejabat lain atau orang lain yang ditetapkan oleh undang-undang.

Akta autentik ialah suatu akta yang dibuat dalam bentuk yang ditentukan undang-undang oleh atau dihadapan pejabat umum yang berwenang untuk itu ditempat akta itu dibuat. ${ }^{5}$ Pasal 1868 KUHPerdata merupakan sumber kewenangan yang dijalankan oleh seorang pejabat umum untuk membuat akta autentik. Pasal tersebut memberikan batasan unsur akta autentik yaitu yang dibuat oleh atau dihadapan pejabat umum, dibuat dalam bentuk yang ditentukan oleh undang-undang dan pejabat umum tersebut harus mempunyai wewenang untuk membuat akta tersebut. Dan untuk dapat digolongkan sebagai sebuah akta maka surat harus ditandatangani sebagai ciri untuk mengindividualisir sebuah akta. ${ }^{6}$

Akta yang dibuat notaris adalah salah satu dasar terwujudnya realisasi pembiayaan. Notaris dalam melakukan suatu tindakan hukum harus senantiasa bertindak secara hati-hati sebelum mengambil keputusan. Dalam menjalankan

${ }^{4}$ Habib Adjie, Hukum Notaris Indonesia, Tafsir Tematik, terhadap UU No.30 Tabun 2004 tentang Jabatan Notaris, Cetakan Ketiga, Refika Aditama, Bandung, 2011, hlm. 17

${ }^{5}$ Lihat Pasal 1868 KUHperdata

6 Sudikno Mertokusumo, Hukum Acara Perdata, Liberty, Yogyakarta, 2012, hlm. 121 
jabatannya, notaris wajib bertindak amanah, jujur, saksama, mandiri, tidak berpihak, dan menjaga kepentingan pihak yang terkait dalam perbuatan hukum.

\section{Rumusan Masalah}

Adapun rumusan masalah yang akan dikaji dalam penelitian ini adalah sebagi berikut: pertama, bagaimanakah peran notaris dalam penerapan good corporate governance pada Perbankan Syariah terhadap proses pembiayaan? Kedua, bagaimanakah formulasi akta notaris pada akad perbankan syariah yang sesuai dengan undang-undang jabatan notaris guna menegakkan good corporate governance perbankan syariah?

\section{Tujuan Penelitian}

Tujuan dari penelitian ini adalah: pertama, mengetahui peran notaris dalam penerapan good corporate governance pada Perbankan Syariah terhadap proses pembiayaan. Kedua, memahami formulasi akta notaris pada akad perbankan syariah yang sesuai dengan undang-undang jabatan notaris guna menegakkan good corporate governance perbankan syariah.

\section{Metode Penelitian}

Jenis penelitian ini adalah yuridis normatif, dengan sumber data sekunder dari sumber hukum primer dan sekunder. Pendekatan yang digunakan adalah pendekatan peraturan perundang-undangan. Data dideskripsikan dengan metode deskriptif kualitatif.

\section{Hasil Penelitian dan Pembahasan}

Peran Notaris dalam Penerapan Good Corporate Governance pada Perbankan Syariah terhadap Proses Pembiayaan

Dalam setiap kegiatan usaha, bank syariah wajib menerapkan tata kelola yang baik, mencakup prinsip transparansi, akuntabilitas, pertanggungjawabaan, profesional dan kewajaran dalam menjalankan kegiatan usahanya. Kegiatan pembiayaan adalah salah satu kegiatan usaha bank syariah yang mana pada Pasal 34 Undang-Undang Perbankan Syariah mewajibkan bagi Bank untuk menerapkan tata kelola yang baik, termasuk dalam hal pembiayaan. 
Kegiatan Pembiayaan merupakan wadah dimana bank dan nasabah bertemu dan melakukan kegiatan usaha, kantor cabang bank adalah tombak dari bank syariah yang berinteraksi langsung dengan masyarakat. Prinsip tata kelola yang baik diharapkan dapat dirasakan oleh masyarakat, prinsip-prinsip tata kelola yang baik menurut studi-studi normatif memandang prinsip tersebut sepenuhnya sejalan dengan ajaran Islam. Prinsip transparansi dalam kegiatan pembiayaan dilakukan dengan memberikan penjelasan kepada nasabah mengenai kemungkinan timbulnya risiko kerugian yang dimaksudkan untuk menjamin transparansi produk dan jasa bank. Prinsip transparansi juga dapat di wujudkan dalam kejelasan kontrak/ akad yang di sepakati.

Perkembangan perbankan syariah di Indonesia berpengaruh pada instrumen lainnya, seperti lembaga notaris yang selama ini terlibat dalam mengeluarkan surat keterangan hukum mengenai akad-akad bisnis syariah.7 Agar suatu perjanjian mendapatkan kekuaatan hukum, maka harus tercatat di hadapan notaris. Karena itu setiap bisnis syariah termasuk didalamnya adalah bisnis syariah adalah selalu membutuhkan notaris sebagai pejabat yang membuat akta otentik sesuai dengan tugasnya yang diatur dalam UU No. 2 Tahun $2014 .^{8}$

Dalam hal pemberian pembiayaan, atau adanya kontrak kerjasama lainnya antara pihak bank dan nasabah, maka pihak bank akan meminta pada notaris untuk membuat suatu akta autentik mengenai hubungan hukum yang mengikat pihak bank dengan debitur, tentu hal ini membutuhkan pengetahuan Notaris yang tidaak hanya secara hukum negara, namun seorang Notaris`harus mengetahui hukum syariat sehingga dalam menerapkan pembuatan akta jaminan ataupun akta kesepakatan bank dan nasabah sesuai dengan aturan hukum dan juga sesuai dengan hukum syariat. ${ }^{9}$

Setiap tansaksi pembiayaan di bank syariah membutuhkan sebuah kontrak. Kontrak atau akad pembiayaan yang dibuat oleh bank dan nasabah dapat dibuat dengan akta di bawah tangan dan/atau akta notariil. Dalam praktek, biasanya

\footnotetext{
${ }^{7}$ Ustad Aidil, Op. Cit., hlm. 40.

8 Ibid., hlm. 85-86.

${ }_{9}^{9}$ Darsono dkk, Op. Cit., hlm. 301.
} 
bank menentukan bentuk akta dilihat dari besarnya nilai pembiayaan yang akan dilakukan. Akta pembiayaan di bawah tangan dibuat sendiri oleh pihak bank melalui kesepakatan dan tawar menawar dengan nasabah. Biasanya akta dibawah tangan dibuat karena para pihak tidak ingin repot dan para pihak ingin menimialisir biaya pembuatan akta, karena dirasa sudah cukup dan mengingat nilai dari pembiayaan tersebut yang tidak terlalu besar. Sedangkan akad pembiayaan notariil dibuat oleh bank dan nasabah di hadapan notaris karena jumlah nilai pembiayaan dan resiko yang besar sehingga dibutuhkan akta otentik sebagai alat bukti yang kuat.

Akad adalah kesepakatan tertulis antara Bank Syariah atau UUS dan pihak lain yang memuat adanya hak dan kewajiban bagi masing-masing pihak sesuaui dengan prinsip syariah. ${ }^{10}$

Dalam melaksanakan perjanjian pembiayaan dengan membuat akta di bawah tangan, ada dua jenis akta yakni, yang pertama pihak bank biasanya hanya melegalisasi akta, yang mana pihak bank dan nasabah menghadap kepada Notaris dengan membawa akad pembiayaan yang telah disepakati dan telah di review oleh dewan pengawas syariah dan disetujui pimpinan kantor cabang bank lalu penandatanganan aktanya dilakukan di hadapan notaris, legalisasi dimaksudkan untuk menetapkan kepastian tanggal dan mengesahkan tanda tangan para pihak. Kedua, yaitu akta pembiayaan yang hanya di daftarkan saja, yakni dengan proses pembuatan kesepakatan dan penandatanganan akta pembiayaan dilakukan tidak dihadapan notaris serta tidak melibatkan notaris. Setelah perjanjian pembiayaan di sepakati dan telah di review oleh dewan pengawas syariah dan disetujui pimpinan kantor cabang bank dan selesai ditandatangani oleh pra pihak, lalu akta tersebut dibawa ke notaris untuk di daftarkan (waarmerking).

Dalam membuat kontrak pembiayaan, bank syariah masih banyak mengacu pada format perjanjian kredit di bank konvensional. Namun demikian, dilakukan juga penyesuaian dalam pasal-pasalnya agar tidak bertentangan dengan prinsip syariah. ${ }^{11}$ Pihak bank memiliki standar kontrak tersendiri terhadap akta

${ }^{10}$ Lihat Pasal 1 Angka 13 Undang-Undang Perbankan Syariah

11 Aunur Rohim Faqih, Bank Syariah; Kontrak Bisnis Syariah \& Penyelesaian Sengketa di Pengadilan, FH UII Press, Yogyakarta 2017, hlm. 205 
pembiayaan yang dibuat dibawah tangan, pihak internal telah menyiapkan dan memformulasikan akta yang telah di review dan di setujui oleh dewan pengawas syariah (DPS). Peran DPS dalam proses pembiayaan salah satunya adalah me review konsep dan garis besar dari pembiayaan yang akan dilakukan, menilai apakah perjanjian pembiayaan tersebut telah memenuhi prinsip-prinsip syariah, yakni pembiayaan tersebut harus bebas dari unsur riba, gharar, maysir dan haram.

Bentuk perjanjian pembiayaan di bank syariah tidak terlepas dari kontaminasi bentuk perjanjian kredit di bank konvensional, bahkan sama. Hanya isi, nafas dan prinsipnya berbeda antara perjanjian kredit di bank konvensional dengan perjanjian pembiayaaan di bank syariah. Untuk pejanjian pembiayaaan di bawah tangan, pihak bank telah memiliki standar tersendiri dalam akadnya, bahkan seperti perjanjian baku (standar contract) karena sifat atau karakternya yang telah ditentukan secara sepihak dan di dalamnya ditentukan sejumlah kalusul yang meringankan pihak bank. Tetapi di dalam pelaksanaanya, nasabah juga dapat mengajukan tawar menawar atau negosiasi guna mencapai kata sepakat serta menghindari perbuatan zalim.

Bank Syariah dalam melaksanakan kegiatan usaha khususnya pembiayaan, wajib menerapkan prinsip-prinsip tata kelola yang baik yang mencakup prinsip transparansi, akuntabilitas, pertanggungjawaban, profesional dan kewajaran, dalam literatur-literatur lain menyebutkan prinsip tersebut dikenal dengan prinsip good corporate governance.

Notaris adalah pejabat umum yang berwenang untuk membuat akta autentik, notaris bukanlah pihak dalam akta, ia berkudukan sebagai pejabat umum yang independen, dan produk hukumya adalah akta, dimana bank sebagai pihak dalam perjanjian membutuhkan jasa notaris untuk membuat akta di bidang perbankan syariah termasuk dalam kegiatan pembiayaaan serta dalam pengikatan jaminannya.

Telah disebutkan diatas bahwa yang wajib menerapkan tata kelola perusahaan yang baik adalah bank, bukan notaris. Notaris membuat akta bukanlah ide atau kemauannya sendiri, melainkan notaris hanya membuat akta atas permintaan para pihak. Tetapi notaris juga dapat mendukung bank menerapkan tata kelola yang baik dengan cara menjalankan dengan baik dan benar kewajiban, kewenangan maupun 
larangan sesuai amanat Undang-Undang Nomor 2 Tahun 2014 tentang Perubahan Atas Undang-Undang Nomor 30 Tahun 2004 tentang Jabatan Notaris.

Notaris dalam memformulasikan kehendak bank dan nasabah untuk dinyatakan dalam akta yang dibuat oleh dan di hadapannya agar sesuai dengan Undang-Undang baik itu peraturan mengenai perjanjian/ kontrak dalam lingkup hukum perdata maupun dalam lingkup Perbankan syariah, serta agar kehendak para pihak tersebut terlaksana secara baik dan benar. Dengan memformulasikan akta dalam akad pembiayaan sekaligus menjalankan fungsi sebagai penasihat hukum dengan memberikan penyuluhan hukum sehubungan dengan pembuatan akta pembiayaan, tetapi lain hal nya dengan notaris yang diartikan "pasrah" hanya menerima begitu saja keterangan dan apa yang di minta para pihak yang akan dituangkan didalam akta, tetapi juga harus berperan aktif dengan membuat penilaian terhadap isi dari akta yang diminta kepadanya dan tidak perlu ragu untuk menyatakan keberatan atau menolak jika kepentingan pihak yang memintanya tidak sesuai dengan kelayakan maupun norma yang berlaku. ${ }^{12}$

Pada prakteknya, kewenangan notaris untuk dapat memberikan penyuluhan hukum sehubungan dengan pembuatan akta sebatas pada:

1. Memberikan pehamaman kepada para pihak mengenai semua akibat hukum yang ditimbulkan karena adanya kesepakatan;

2. Memberikan saran bagi kedua belah pihak mengenai jumlah yang tidak wajar;

Hal tersebut dikarenakan, pihak bank telah memiliki ketentuan-ketentuan tersendiri dalam rangka memberikan jasa keuangan khususnya kegiatan pembiayaan, nasabah hanya mengikuti atau patuh ketentuan yang sudah ditetepkan oleh pihak bank. Hal ini mengingat adanya asas kebebasan berkontrak, dengan asas kebebasan berkontrak, orang dapat bebas untuk dengan siapa ia ingin membuat perjanjian serta kebebasan untuk memilih causa perjanjian yang akan dibuatnya. Asas ini menenkankan bahwa orang bebas untuk mengikatkan diri kepada orang lain, kapan dan bagaimana yang diinginkan.

12 A.A Andi Prajitno, Op. Cit., hlm. 5 
Dalam perkembangannya, ternyata kebebasan berkontrak dapat menimbulkan ketidakadilan, karena untuk mencapai asas kebebasan berkontrak harus didasarkan pada posisi tawar para pihak yang seimbang. Dalam kenyataannya, hal tersebut sulit dijumpai adanya kedudukan posisi tawar yang betul-betul seimbang. ${ }^{13}$ Sama halnya dengan posisi bank dan nasabah, bank memiliki posisi tawar yang lebih tinggi sehingga banyak kemungkinan ia dapat mendikte nasabah untuk mengikuti ketentuannya dalam perumusan isi perjanjian.

Dalam keadaan demikian, pemerintah atau negara seringkali melakukan intervensi atau pembatasan kebebasan berkontrak dengan tujuan untuk melindungi pihak yang lemah, pembatasan tersebut dapat dilakukan melalui peraturan perundang-undangan dan putusan pengadilan. ${ }^{14}$ Salah satunya yakni dengan mengundangkan undang-undang tentang Jabatan Notaris yang didalamnya memuat ketentuan mengenai Notaris sebagai pejabat umum yang berwenang membuat akta autentik serta kewenangan, kewajiban dan larangannya menjadi penyaring atau filter terakhir sebelum perjanjian dilaksanakan. Filter terakhir inilah yang berfungsi meminimaisir resiko dan sengketa yang mungkin akan datang di kemudian hari akibat terjadinya kesepakatan yang dilakukan oleh para penghadap.

\section{Formulasi Akta Notaris Pada Akad Perbankan Syariah yang Sesuai dengan Undang-Undang Jabatan Notaris Guna Menegakkan Good Corporate Governance Perbankan Syariah}

Notaris dalam memformulasikan akta perbankan syariah, harus memperhatikan dan menerapkan hal yang diatur didalam Undang-Undang Jabatan Notaris, serta pentingnya pemahaman di bidang perbankan syariah. Didalam praktek, akta pembiayaan pada perbankan syariah dapat di buat dalam dua jenis, yakni akta yang dibuat di bawah tangan dan akta yang di buat secara notariil. Peraturan khusus mengenai bentuk akta syariah atau klausul akta akad syariah (kontrak) belum ada sampai sejauh ini. Pada prakteknya, akad yang dibuat

${ }^{13}$ Ridwan Khairandy, Hukum Kontrak Indonesia dalam Prespektif Perbandingan, FH UII Press, Yogyakarta, 2013, hlm. 88

${ }^{14}$ Ibid., hlm. 89 
antara pihak bank dan nasabah masih mengacu pada hukum positif, Begitu juga akad pembiayaaan yang dibuat notariil.

Seorang Notaris mempunyai tanggung jawab terhadap akta akad pembiayaan Perbankan Syariah yang dibuat dihadapannya secara otentik. Terhadap akta akad tersebut Notaris mempunyai tanggung jawab penuh tentang kebenaran dan ketepatan konstruksi akad agar terpenuhinya syarat subyektif maupun obyektif atas akad/perjanjian tersebut, sehingga akta akad yang dibuat di hadapan Notaris tersebut benar dan secara otentik sangat mendasar menjadi akta akad yang mempunyai kekuatan nilai pembuktian yang sempurna, yang dapat dinilai dari aspek lahiriah, formal dan materiel. Notaris dalam memformulasikan akta akad atas permintaan para pihak berdasar pada tata cara atau mekanisme/prosedur pembuatan akta Notaris.

Apabila para pihak menganggap ada yang tidak benar dari akta tersebut dan menderita kerugian sebagai akibat langsung dari akta tersebut maka pihak dimaksud harus menggugat Notaris dan wajib membuktikan apakah akta Notaris tersebut tidak memenuhi aspek lahiriah, formal atau materiel dan membuktikan kerugiannya. Notaris harus bertanggung jawab penuh atas konstruksi akta akad sejak akta akad tersebut diformulasikan kedalam akta, sehingga jika terjadi sengketa pada akta akad yang dinyatakan tidak sah dan/atau batal demi hukum yang merujuk pada mekanisme pembuatan akta akadnya Notaris harus mempertanggung jawabkannya bahkan ketika kemudian oleh Hakim diputuskan untuk membayar ganti rugi yang diderita oleh para subyek sebagai akibat langsung dari adanya kesalahan konstruksi akta akad yang dibuat oleh Notaris. Oleh karenanya Notaris perlu memperhatikan dengan seksama bagaimana bentuk akta akad yang dibuat dihadapannya agar sesuai serta tidak melanggar ketentuan yang telah ditetapkan dalan UUJN-P. ${ }^{15}$

\section{Bentuk Akta yang Sesuai dengan Undang-Undang Jabatan Notaris}

Akta pembiayaan di bank syariah yang dibuat secara notariil harus mengikuti bentuk yang di tentukan oleh undang-undang, dalam hal ini adalah Undang-

15 Pandam Nurwulan, Akad Syariah Berdasar Hukum Ekonomi Islam dan Aplikasinya dalam Akta Notaris, Makalah, Program Doktor Ilmu Hukum, Fakultas Hukum Universitas Islam Indonesia, Yogyakarta, 2017 hlm.12 
Undang Nomor 2 Tahun 2014 tentang Perubahan atas Undang-Undang Nomor 30 Tahun 2004 tentang Jabatan Notaris.

Dalam tataran praktek, ada Notaris yang mencantumkan kalimat "Bismillahirrahmanirrahim" di awal akta dan "Alhamdulillahirabbilalamin" di akhir atau penutup akta pada akad pembiayaan syariah. Dalam melakukan hal tersebut bukan tanpa alasan, salah satu alasannya adalah membedakan bahwa akta yang dibuatnya adalah akta pembiayaan di bidang syariah. ${ }^{16}$ Sejatinya bagi seorang muslim, penggunaan kalimat seperti tersebut diatas dalam setiap memulai kegiatan adalah lumrah atau wajar, karena muslim terbiasa dalam mengamalkan kalimat Bismillah sebagai niat yang murni, yang menunjukan niat melakukan sesuatu karena Allah. Sama halnya dengan menambah kalimat "Alhamdulillahirabbilalamin" pada akhir atau penutup akta, pemberian kalimat tersebut juga bertentangan dengan Pasal 38 ayat (4).

Pasal 38 secara jelas mengatur mengenai awal akta atau kepala akta, isi akta, serta akhir atau penutup akta, sehingga apabila ada akta yang tidak sesuai dengan Pasal tersebut dapat dianggap melanggar UUJNP dan kehilangan ke otentikan sebuah akta. Akta notaris tersebut menjadi tidak otentik karena tidak dibuat dalam bentuk yang sesuai dengan undang-undang. Hal ini sesuai dengan Pasal 41 UUJNP yang berbunyi "pelanggaran terhadap ketentuan sebagaimana dimaksud dalam Pasal 38, Pasal 39, dan pasal 40 mengakibatkan akta hanya mempunyai kekuaatan pembuktian sebagai akta dibawah tangan"

Sebagaimana penelitian yang dilakukan oleh Febriyanti Dwi Putri dalam Tesisnya yang berjudul "Kedudukan Akta Perbankan Syariah yang dibuat oleh Notaris menurut UU No. 2 Tahun 2014 tentang Perubahan Atas UU No. 30 Tahun 2004 tentang Jabatan Notaris" memberi kesimpulan bahwa Akta Notaris di bidang Perbankan Syariah yang mencantumkan "Bismiilahirrahmanirrahim" di awal aktanya bertentangan dengan Undang-Undang Jabatan Notaris dan memiliki kedudukan sebagai akta tidak otentik yakni mempunyai kekuatan pembuktian yang tidak sempurna sebagaimana akta di bawah tangan.

16 Wawancara dengan Notaris Kota Yogyakarta, 08 Desember 2017 
Penulis memiliki pendapat yang sama dengan penelitian diatas yang memberi kesimpulan bahwa akta Notaris di bidang Perbankan Syariah yang mencantumkan "Bismillahirrahmanirrahim" diawal akta adalah bertentangan dengan Undang-Undang Jabatan Notaris dan memiliki kedudukan sebagai akta tidak otentik dan mempunyai kekuatan pembuktian yang tidak sempurna sebagaimana akta dibawah tangan.

Pencantuman kalimat seperti tersebut pada awal akta perbankan syariah tidak selaras dengan ketentuan Pasal 38 ayat (2) UUJN-P dan dapat disimpulkan bahwa akta tersebut telah cacat hukum dalam segi formalitas atau bentuknya karena salah satu syaratnya tidak dipenuhi, kedudukan akta seperti itu terdegradasi kedudukannya dari akta otentik menjadi mempunyai nilai kekuatan pembuktian sebagai akta di bawah tangan sesuai dengan ketentuan Pasal 1869 KUHPerdata. ${ }^{17}$ Pasal 1869 KUHPerdata telah menentukan batasan akta otentik (akta notaris) yang mempunyai nilai kekuatan pembuktian sebagai akta di bawah tangan dapat terjadi jika tidak memenuhi ketentuan karena:

(1) Tidak berwenangnya pejabat umum yang bersangkutan,

(2) Tidak mampunya pejabat umum yang bersangkutan, atau

(3) Cacat dalam bentuknya.

Meskipun demikan, akta seperti itu tetap mempunyai kekuatan pembuktian sebagai akta di bawah tangan jika akta tersebut di tandatangani dan diakui oleh para pihak.

Agar tidak melanggar ketentuan Pasal 38 UUJN dengan menambahi kalimat Bismillah di awal akta dan memiliki resiko akta menjadi terdegradasi menjadi akta tidak otentik dan memiliki kekuatan pembuktian seperti akta dibawah tangan, kalimat Bismillahirrahmanirrahim dapat di letakkan pada bagian isi akta. Isi akta memuat kehendak dan keinginan dari pihak yang berkepentingan, terlebih lagi pihak dalam posisi lingkup perbankan syariah.

Sudah seharusnya dan semestinya akta syariah yang merupakan produk Perbankan Syariah yang akan diformulasikan secara otentik ke dalam Akta Notaris hendaknya dibuat berdasar dan sesuai dengan UUJN-P yaitu dalam Pasal 38 ayat

${ }^{17}$ Habib Adjie dan Muhammad Hafidh, Op. Cit., hlm. 59 
(2). Hal tersebut dapat dilakukan oleh seorang Notaris dengan cara memindahkan dan/ atau meletakkan ketentuan ketentuan kalimat yang menjadi landasan Syariah dari sifat/jenis akta akad Syariah baik berdasar Al-Qur'an maupun Hadist, pada bagian isi akta atau pada akhir praemisse.

\section{Isi dari Akad Perbankan Syariah}

Isi dari akad adalah kesepakatan para pihak. Dalam memformulasikan isi atau membuat kerangka akta yang di kehendaki para pihak, Notaris diharapkan menerapkan amanat Undang-Undang Jabatan Notaris mengenai kewenangan dan kewajiban Notaris.

Di dalam praktek, bank telah menyiapkan formulasi sendiri dalam membuat akad pembiayaan, selanjutnya diserahkan kepada notaris yang disertai surat order untuk dibuatkan menjadi notariil akta. Walaupun pihak bank telah menyiapkan sendiri draft dari akadnya, Notaris tetap membuat kerangka akta, hal ini adalah bentuk dari kecermatan dan kehati-hatian notaris dalam membuat akta.

Pada prakteknya, ketentuan dan klausul-klausul yang terdapat pada akta pembiayaan di bidang perbankan syariah masih mengacu pada hukum positif dan masih memakai istilah perjanjian konvensional seperti :

(1)Pembebanan/ Agunan/ Jaminan yang berupa Hak Tanggungan, Fidusia, Cash Collaterall, Gadai, Personal Guarantee, dll; 18

(2)Angsuran;

(3)Surat sanggup;19

(4)Pembayaran kembali/ pelunasan utang;

(5)Biaya, Potongan dan Pajak;

(6)Cedera janji/ akibat cedera janji;

(7)Force majeur;20

(8)Risiko dan Asuransi;

(9)Penyelesaian sengketa; dll.

${ }^{18}$ Ketentuan jaminan didalam akad pembiayaan syariah masih menggunakan konsep jaminan seperti di perbankan konvensional, hal ini dikarenakan peraturan mengenai konsep jaminan yang dikhususkan untuk perbankan syariah belum ada. Dalam perbankan syariah, jaminan dimaksudkan untuk kebaikan dan keamanan bagi kedua belah pihak (bank dan nasabah).

${ }^{19}$ Ketentuan adanya surat sanggup pada akad pembiayaan syariah memiliki tujuan yang sama dengan perjanjian kredit di bank konvensional, yakni bertujuan untuk mempertegas bahwa nasabah sanggup melaksanakan seluruh kewajibannya

${ }^{20}$ Harus diakui bahwa peraturan tentang force majeure dalam akad syariah masih menjadi barang langka sehingga jelas-jelas tidak mengakomodasi kepentingan nasabah. Lihat Rifqi Hidayat Muhammad (2015) Analisis Hukum Kontrak Syariah Terhadap Klausul Force Majeure Dalam Akad Murabahah. Tesis, Pascasarjana. IAIN Antasari Banjarmasin, link:http://idr.iain-antasari.ac.id/178/, di akses tanggal 3 Februari 2017. 
Dalam membuat kontrak pembiayaan bank syariah masih banyak mengacu pada format perjanjian kredit di bank konvensional, namun demikian dilakukan juga penyesuaian dalam pasal-pasalnya agar tidak bertentangan dengan prinsipprinsip syariah. Penyesuaian yang dilakukan berpedoman pada hukum Islam yang berlaku, dan juga mengacu juga kepada ketentuan hukum positif Indonesia. Yang harus diperhatikan dalam pembuatan akad antaara lain Undang-Undang tentang Perbankan Syariah, Undang-Undang Perseroan Terbatas, Surat Keputusan Direksi Bank Indonesia, Fatwa Dewan Syariah Nasional (DSN), dan lain sebagainya. ${ }^{21}$

Notaris dalam menjalankan tugas jabatannya mengikuti ketentuan hukum yang berlaku, didalam praktek bisnis perbankan syariah belum ada peraturan khusus mengenai akad pembiayaan syariah termasuk ketentuan yang membatasi mengenai klausul-klausul pembiayaan, maka dari itu notaris juga tidak dituntut untuk menambahi atau merubah sendiri ketentuan dan kebiasaan yang selama ini di praktekan. Hingga saat ini ini notaris cukup dan memang hanya mematuhi ketentuan-ketentuan undang-undang jabatan notaris dan ketentuan umum mengenai perbankan syariah.

Ketidakselarasan antara akad pembiayaan sebagai perjanjian pokok dan pemebanan jaminan sebagai perjanjian tambahan bukan wewenang notaris untuk mengatur dan merubah sendiri ketentuan khusus mengenai jaminan agar selaras, tetapi tugas negara lah yang harus memberi perhatian lebih kepada bisnis perbankan syariah yang selama ini masih mengambil begitu saja konsep jaminan konvensional.

Klausula yang ada didalam akad meskipun masih mengacu pada hukum positif, selama tidak bertentangan dengan syar'i dan juga ada nilai maslahatnya dapat diterima oleh hukum Islam. Bentuk akad/kontrak seperti apapun jika belum ada ketentuan yang melarangnya maka itu sah, karena hakekat dari perjanjian itu sendiri adalah menurut maksud/ tujuan dan maknanya, bukan menurut lafadz, bentuk serta susunan katanya atau redaksinya. ${ }^{22}$

Akad pembiayaan maupun perjanjian kredit dari sisi bentuk memang sama, apalagi jika kedua akta itu dibuat menjadi akta notariil, yang bentuknya telah di tentukan oleh undang-undang jabatan notaris, tetapi dari isi, nafas, dan prinsipnya 
berbeda. Notaris dalam memformulasikan akad pembiayaan di bank syariah diharapkan berperan aktif guna memeriksa segala aspek hukum dan kelengkapan yang diperlukan.

\section{Penutup}

Salah satu pilar dari penerapan corporate governance yang efektif adalah adanya suatu kejelasan dalam kontrak. Akta menjadi suatu hal yang sangat krusial dalam kegiatan pembiayaaan di bank syariah, karena akta merupakan salah satu penentu terlaksananya GCG. Notaris adalah filter terakhir sebelum pembiayaaan direalisasikan/ dicairkan, mengingat akad pembiayaan yang dibuat oleh dan di hadapan notaris menjadi akta otentik yang memiliki kekuatan pembuktian sempurna, maka dari itu notaris dapat berperaan sebagai pihak yang mendukung penegakkan GCG pada bank syariah.

Notaris dapat mendukung terciptanya tata kelola yang baik bagi bank, yakni memformulasikan kehendak bank dan nasabah dalam akad pembiayaan menjadi akta otentik. Bentuk akta notariil tentukan oleh Undang-Undang Nomor 2 Tahun 2014 Tentang Perubahan Atas Undang-Undang Nomor 30 Tahun 2004 Tentang Jabatan Notaris, peraturan tersebut berlaku juga untuk akta-akta yang berkaitan dengan perbankan syariah, khususnya pada akad pembiayaan, mengingat peraturan khusus mengenai akta yang berkaitan dengan perbankan syariah belum ada. Maka Notaris harus melakukan atau membuat terobosan guna mengkompromikan antara berbagai ketentuan yang belum semuanya sejalan. Dalam pembuatan akta pembiayaan, isi maupun klausul yang terdapat dalam akad pembiayaan syariah masih megacu pada hukum positif, serta masih mengacu pada format perjanjian kredit di bank konvensional, tetapi dilakukan penyesuaian dalam pasal-pasalnya agar tidak bertentangan dengan prinsip syariah. Walaupun perjanjian kredit dan akad pembiayaan menurut bentuk dan isinya sama, tetapi antara akad pembiayaaan dan perjanjian kredit memiliki prinsip, tujuan, isi, dan nafas yang berbeda. 


\section{Daftar Pustaka}

\section{Buku}

Prajitno, A.A Andi, Pengetahuan Praktis Tentang Apa dan Siapa Notaris di Indonesia, Perwira Media Nusantara, Surabaya, 2015.

Rohim Faqih, Aunur, Bank Syariah ; Kontrak Bisnis Syariah \& Penyelesaian Sengketa di Pengadilan, FH UII Press, Yogyakarta, 2017.

Triyanta, Agus, Hukum Perbankan Syariah, Setara Press, Malang, 2016.

Adjie, Habib, Hukum Notaris Indonesia, Tafsir Tematik terhadap UU No. 30 Tahun 2004 tentang Jabatan Notaris, Refika Aditama, Bandung, 2011.

Nurwulan, Pandam, Akad Syariah Berdasar Hukum Ekonomi Islam dan Aplikasinya dalam Akta Notaris, Makalah, Program Doktor Ilmu Hukum, Fakultas Hukum Universitas Islam Indonesia, Yogyakarta, 2017.

Khairandy, Ridwan, Hukum Kontrak Indonesia dalam Prespektif Perbandingan, FH UII Press, Yogyakarta, 2013.

Shidarta, Moralitas Profesi Hukum, suatu Tawaran Kerangka Berpikir, Refika Aditama, Bandung, 2009.

Mertokusumo, Sudikno, Hukum Acara Perdata, Liberty, Yogyakarta, 2012.

Aidil, Ustad, Mengenal Notaris Syariah, Citra Aditya Bakti, Bandung, 2011.

\section{Internet}

http://download.portalgaruda.org/

\section{Peraturan Perundang-Undangan}

Kitab Undang-Undang Hukum Perdata

Undang-Undang Nomor 2 tahun 2014 Tentang Perubahan Atas Undang-Undang Nomor 30 Tahun 2004 Tentang Jabatan Notaris

Undang-Undang Nomor 21 Tahun 2008 tentang Perbankan Syariah 